\title{
First fossil Schizopteridae (Hemiptera: Heteroptera) in Miocene amber from Chiapas, Mexico
}

\section{Primer fósil de Schizopteridae (Hemiptera: Heteroptera) en ámbar del Mioceno de Chiapas, México}

Paulina Gifuentes-Ruiz ${ }^{1}$, Harry Brailovsky ${ }^{1}$, María de Lourdes Serrano-Sánchez ${ }^{2}$, Francisco J. Vega ${ }^{3, *}$

${ }^{1}$ Instituto de Biología, Universidad Nacional Autónoma de México, Coyoacán, CDMX, 04510, Mexico.

${ }^{2}$ Facultad de Ciencias, Universidad Nacional Autónoma de México, Coyoacán, CDMX, 04510, Mexico.

${ }^{3}$ Instituto de Geología, Universidad Nacional Autónoma de México, Coyoacán, CDMX, 04510, Mexico.

* Corresponding author: (F.J. Vega)

vegver@unam.mx

\begin{abstract}
A new genus and species of Hypselosomatinae (Heteroptera: Dipsocoromorpha), Hypsotsijilia bretoni Cifuentes-Ruiz and Brailovsky gen. nov., sp. nov. is herein described based on a female specimen. It represents the first fossil record of Schizopteridae in the early Miocene amber from Chiapas, Mexico. It is compared with related taxa and the estuarine paleoenvironment is discussed, matching the one previously cited for the subfamily in other estuarine amber deposits.
\end{abstract}

Keywords: Hemiptera, Heteroptera, Schizopteridae, Hypselosomatinae, amber, Miocene, Chiapas, Mexico.

\section{RESUMEN}

Se describe un nuevo género y especie de Hemiptera, Hypsotsijilia bretoni CifuentesRuiz y Brailovsky, con base en un espécimen hembra. Se trata del primer fósil de Schizopteridae registrado para el ámbar del Mioceno temprano de Chiapas, México. Se compara con los taxa relacionados, y se discute su paleoambiente, el cual coincide con el citado para hallazgos de la subfamilia en otros depósitos estuarinos de ámbar.

Palabras clave: Hemiptera, Heteroptera, Schizopteridae, Hypselosomatinae, ámbar, Mioceno, Chiapas, México.
How to cite this article:

Cifuentes-Ruiz, P., Brailovsky, H., SerranoSánchez, M. L., Vega, F. J., 2021, First fossil Schizopteridae (Hemiptera: Heteroptera) in Miocene amber from Chiapas, Mexico: Boletín de la Sociedad Geológica Mexicana, 73 (3), A170121. http://dx.doi.org/10.18268/ BSGM2021v73n3a170121

Manuscript received: October 10, 2020

Corrected manuscript received: January 11, 2021

Manuscript accepted: January 15, 2021

Peer Reviewing under the responsibility of Universidad Nacional Autónoma de México.

This is an open access article under the CC BY-NC-SA license(https://creativecommons.org/licenses/by-nc-sa/4.0/) 


\section{Introduction}

Amber pieces from Campo La Granja mines near Simojovel, Chiapas, include a diverse, abundant, and well-preserved aquatic and semiaquatic fauna (mainly Crustacea), represented by harpacticoid copepods (Huys et al., 2016), ostracods (MatzkeKarasz et al., 2019), isopods (Broly et al., 2018), parasitic bopyrid isopods (Serrano-Sánchez et al., 2016a), sesarmid crabs (Serrano-Sánchez et al., 2016b), caridean shrimp (Du et al., 2019), tanaidaceans (Heard et al., 2018) and semiaquatic and terrestrial amphipods (Hegna et al., 2020). This peculiar association is interpreted as an estuarine assemblage of microscopic aquatic crustaceans and insects, deposited in a mangrove substrate near the ancient Gulf of Mexico coast (Serrano-Sánchez et al., 2015). Palaeobotanical evidences support the estuarine environment during the earliest Miocene (Langenheim et al., 1967; Cobben, 1971; Frost and Langenheim, 1974; Poinar, 1992; Langenheim, 1995; Graham, 1993; Poinar and Brown, 2002; García-Villafuerte, 2009; Calvillo-Canadell et al., 2010; Solórzano-Kraemer, 2010). According to Serrano-Sánchez et al. (2015), the Campo La Granja amber was deposited as a very fluid resin in temporal ponds and pools on the estuary substrate, where tides transported the small arthropods still alive; they became incorporated in the fluid resin along with coarse quartz sand grains, resulting in stratified amber pieces, completely different from the typical amber pieces from the Mazantic Shales, which includes organic matter but no sediment at all, including terrestrial organisms such as chelicerate arthropods, insects, fungi, and plant remains. For location map and geological information, please refer to Serrano-Sánchez et al., (2015).

The Dipsocoromorpha is one of the smallest and less studied infraorders of Heteroptera (Hemiptera), its size ranges between 0.5 and $4 \mathrm{~mm}$, and specimens are associated with cryptic habitats Weirauch and Fernandes, 2015; Weirauch and Frankenberg, 2015). Within Dipsocoromorpha, the Schizopteridae is the most numerous family
(Henry, 2009), whose species live in wet soils and litter, being common in mosses and behind rocks near the edge of rivers and streams. The group has a worldwide distribution in tropical and subtropical areas, being more abundant in humid tropics. Many schizopteroids have coleopteroid forewings, which means that the wings resemble certain beetles' elytra. The body is usually rounded and wide, with large, whip-shaped antennae bearing large setae (Emsley, 1969; Grimaldi and Engel, 2005). The Schizopteridae includes approximately 350 described species, assigned to two subfamilies: Hypselosomatinae and Schizopterinae (Knyshov et al., 2020). The Hypselosomatinae includes 16 genera and 77 species (Albuquerque-Almeida et al., 2019) and is well-known in Australasia (Hill, 1984; 1991). In the Americas, four genera represent this subfamily: Glyptocombus Heidemann 1906, Ommatides Uhler 1894, Hypselosomops Hoey-Chamberlain and Weirauch, 2016, and Hypsohapsis Hoey-Chamberlain and Weirauch 2016. In Mexico, Glyptocombus has been found in Chiapas (Weirauch and Hoey-Chamberlain, 2018; Hoey-Chamberlain and Weirauch, 2019). The Schizopteridae is an old group, which the oldest record corresponds to a Hypselosomatinae from the Early Cretaceous amber of Lebanon (Azar and Nel, 2010). In fact, Hypselosomatinae includes the most abundant fossil record of Schizopteridae (Chen et al., 2019). Perrichot et al., (2007) reported two genera in the Early Cretaceous amber from France and Myanmar. These fossils were related to Hypselosoma Reuter 1891, suggesting that the origin of this infraorder goes back to the Early Mesozoic. Another genus in the Myanmar amber was reported by Chen et al., (2019). Grimaldi and Engel (2005) suggested that the dipsocoromorphs exist since Triassic times, based on a fossil record from the Late Triassic Virginia shales.

Poinar and Brown (2014) described three species from the Dominican amber, identified as modern genera: Hypselosoma dominicana Poinar and Brown, Schizoptera dominicana Poinar and Schizoptera hispaniolae Poinar. Hoey-Chamberlain and Weirauch (2019) reexamined $H$. dominicana and concluded 
it presents affinities with genera from the Americas, not with Hypselosoma, however, they refrained from moving this species intro a new combination. Finally, for the early Miocene amber of Chiapas, the locality where the sample originated, there is one record for the Ceratocombidae of the same infraorder (Dipsocoromorpha) (Azar et al., 2010). The genus and species herein described represent an extension of the fossil record of the Hypselosomatinae in the Americas and the first record of the Schizopteridae in the early Miocene amber from Chiapas. The paleoenvironment reported for Hypselosomatinae found in Cretaceous amber (Perrichot et al., 2007) is coincident with the estuarine environment interpreted for the Miocene amber of Chiapas.

Specimens are deposited at the Museo de Paleontología "Eliseo Palacios Aguilera", Secretaria de Medio Ambiente e Historia Natural (IHNFG), Tuxtla Gutiérrez, Chiapas under acronym IHNFG.

\section{Systematic Paleontology}

Family Schizopteridae Reuter, 1891

Subfamily Hypselosomatinae Esaki and Miyamoto, 1959

Hypsotsijilia Cifuentes-Ruiz and Brailovsky gen. nov.

Figures 1-6

Type species: Hypsotsijilia bretoni Cifuentes-Ruiz and Brailovsky gen. et sp. nov.

Diagnosis: Clypeus with long setae, pronotum rectangular, elytra base narrow with respect to pronotum base; lateral margins of elytra, convex. Elytriform forewing not areolate, wide veins, elongate, oval cells, four oval cells under subcostal cell. Legs with medium number of setae.

Description: Female. Ovoid body. Clypeus with up to ten thin setae, pronotum rectangular, elytra base narrow with respect to pronotum base; lateral margins of elytra, convex. Elytriform forewings not areolate, wide veins, elongate, oval cells, four oval cells under subcostal cell. Legs with medium number of setae. Legs with up to seven spiniform macrosetae. Female. Coleopteroid. Body length: $1.49 \mathrm{~mm}$ (from the head to the apex of elytra), width $0.77 \mathrm{~mm}$. Brown to dark brown, except the wing cells, that are transparent. Head (Figures 1 to 4). Width including compound eyes, $0.58 \mathrm{~mm}$, three times wider than long. Eyes well developed and big, overlapping the lateral margins of pronotum, width $0.12 \mathrm{~mm}$ in dorsal view (almost $1 / 4$ of interocular distance). Antennae four segmented, with length about $0.08 \mathrm{~mm}, 0.12 \mathrm{~mm}$, $0.38 \mathrm{~mm} 0.42 \mathrm{~mm}$. The first two much shorter, 1.6 to 2 times longer than wide; the two last 42 to 43 longer than wide. The third and fourth segments with long setae (from $0.06 \mathrm{~mm}$ to $0.12 \mathrm{~mm}$ length), symmetric, disperse. Clypeus with at least ten thin setae. Labium $0.36 \mathrm{~mm}$ long, reaching posterior margin of anterior coxa. Buccula with a pair of lateral large setae. First labial segment $0.14 \mathrm{~mm}$ long, with a pair of large setae, second segment $0.08 \mathrm{~mm}$, third segment $0.04 \mathrm{~mm}$, and fourth segment $0.06 \mathrm{~mm}$. Third and fourth segments with at least three thick setae. Thorax (Figures 1, 2 and 4). Pronotum rectangular, length $0.26 \mathrm{~mm}$, width $0.52 \mathrm{~mm}$, greatest width at the base. Pronotal collar prominent, length $0.07 \mathrm{~mm}$ towards the middle. Scutellum 1/6 elytra length, subtriangular, with blunt apex. Legs (Figures 1 and 4). Tarsal formula $2 / 2 / 3$. Anterior coxae extending from the second third of the eye length. Fore femora and middle femora as long as fore tibia and middle tibia. Hind tibia twice the length of hind femora. Long setae and medium setal density on femorae and tibiae; hind femora with a pair of thick spiniform preapical setae; metatibiae with at least eight spiniform setae. Thin setae $0.03 \mathrm{~mm}$ long, spiniform setae $0.07 \mathrm{~mm}$ long. Measurements of legs (in $\mathrm{mm}$ ): length of fore femora, 0.44 , fore tibia 0.41 , fore tarsus 0.10 ; length of middle femora 0.42 , middle tibia 0.44 , middle tarsi 0.17 ; length of hind femora 0.35 , hind tibia 0.70 , hind tarsi 0.33 . Wings (Figures 1A, 1C, 1D and 4A). Fore wings elytrous, length $1.08 \mathrm{~mm}$, width $0.37 \mathrm{~mm}$, covering and slightly extending beyond the abdomen $(0.1 \mathrm{~mm})$. 

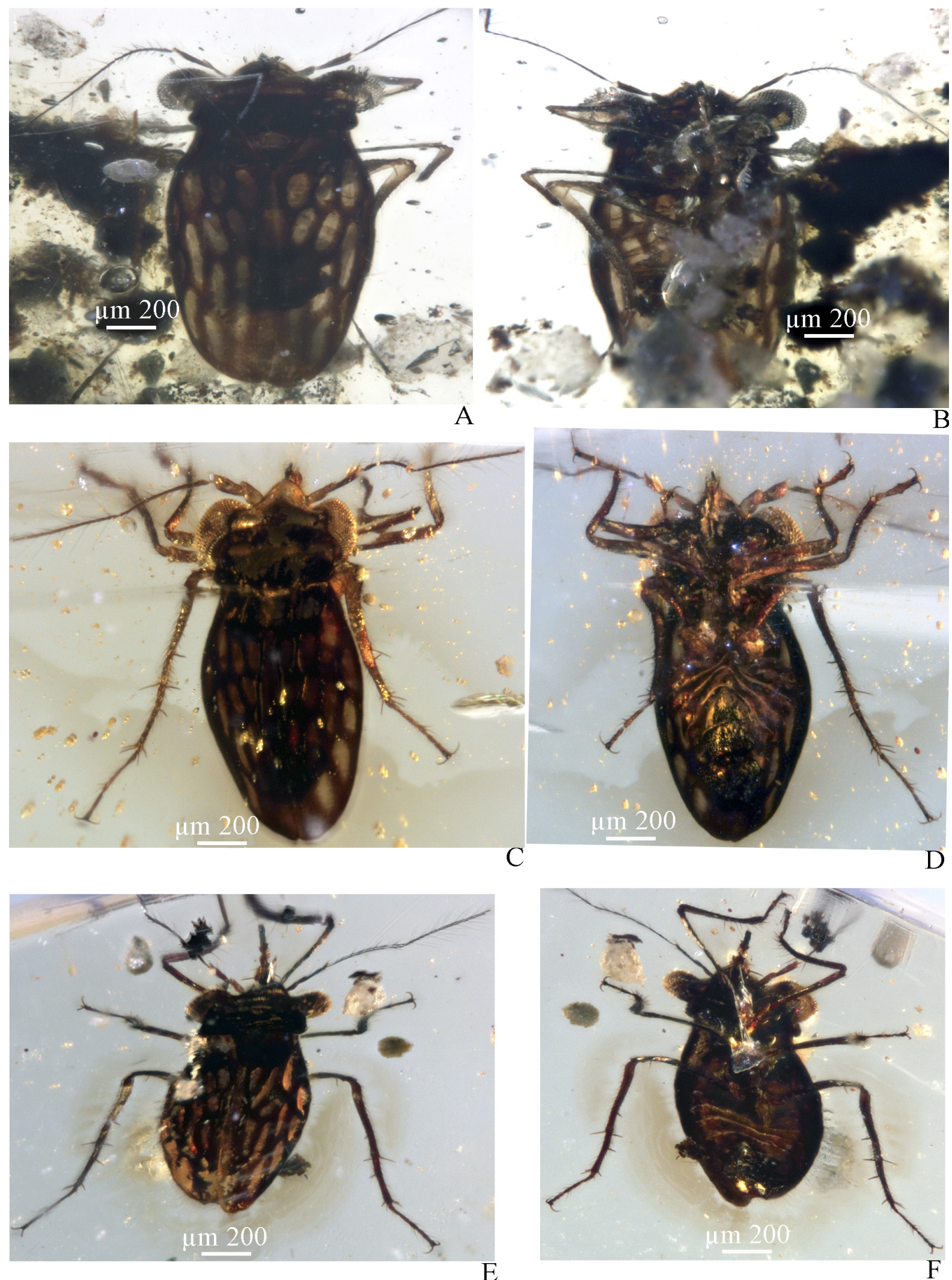

Figure 1 Dorsal and ventral view of three specimens of Hypsotsijilia bretoni Cifuentes-Ruiz and Brailovsky gen. et sp. nov. Important taxonomic characters are visible, such as eyes, mouthparts, antennae, pronotum, legs and the elytriform forewing pattern. 
Base of elytra slightly narrower than base of pronotum, and lateral margins of elytra, which are convex. Wing veins prominent, eleven wing cells large and elongate or oval in each elytron, five of them marginal (four under the subcostal cell). Abdomen (Figures 4B and 5A). Seven visible sternites. Length $0.78 \mathrm{~mm}$, and greatest width 0.66 $\mathrm{mm}$, spiracles not visible. The most apical portion of posterior gonapophysis (eight) visible.

Etymology: Hypso is the prefix of several genera in the Hypselosomatinae, tsijil is a tsotsil word to design Hemiptera insects. Tsotsil is the predominant language of the original communities from Simojovel de Allende, Chiapas, Mexico.

Distribution: La Quinta Formation, Finca Carmitto Member, Lower Miocene, Campo La Granja, Simojovel, Chiapas.

\section{Hypsotsijilia bretoni Cifuentes-Ruiz and Brailovsky gen. et sp. nov.}

Figures 1- 6

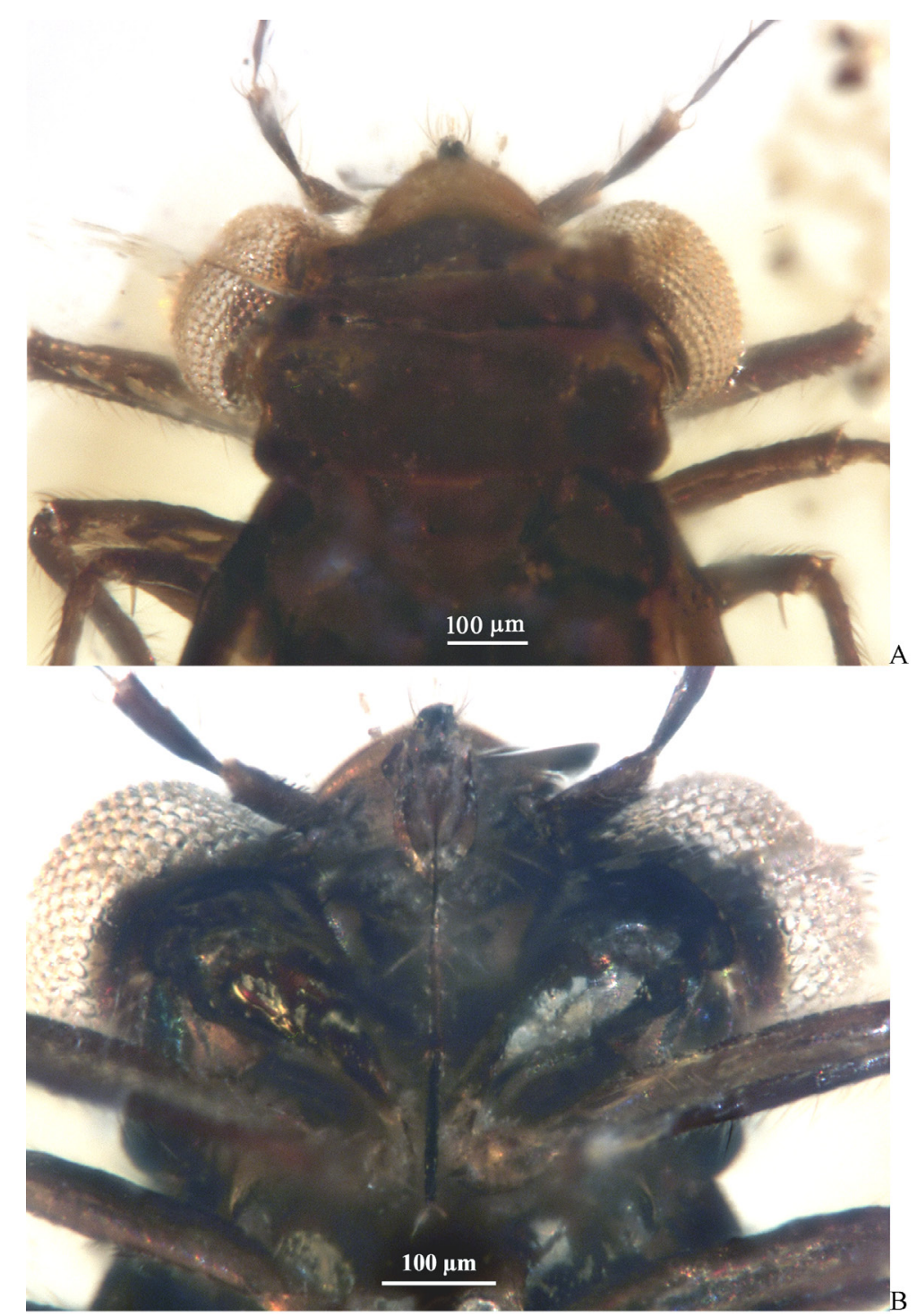

Figure 2 Dorsal (A) and ventral (B) view of the head and pronotum. Prominent eyes, a rectangular pronotum and the pronotal collar are visible (A). Head and mouthparts such as clypeus, labrum and labium with several setae are visible from the ventral view, fore coxae can be appreciated too (B). 
Diagnosis: As for genus.

Description: As for genus.

Etymology: The species is dedicated to the memory of Gérard Breton, brilliant French paleontologist with many important contributions to the study of flora and fauna preserved in amber.

Material examined: Holotype IHNFG5960, paratypes IHNFG-5961 to IHNFG-5966.

Type locality: La Quinta Formation, Finca Carmitto Member, early Miocene, Campo La Granja, Simojovel, Chiapas.
Taxonomy: The characters of the specimen that match with the infraorder Dipsocoromorpha are: small size, head often declivous, antennae with short scape and pedicel, and two long, thin flagellomeres covered with long setae (Štys, 1995). In many species of Schizopteridae, including the specimens herein observed, the forewing is not clearly divided into corium and membrane, instead, it is completely elytrous, coleopteroid (Weirauch and Fernandes, 2015). Likewise, the specimens can be placed in the subfamily Hypse-
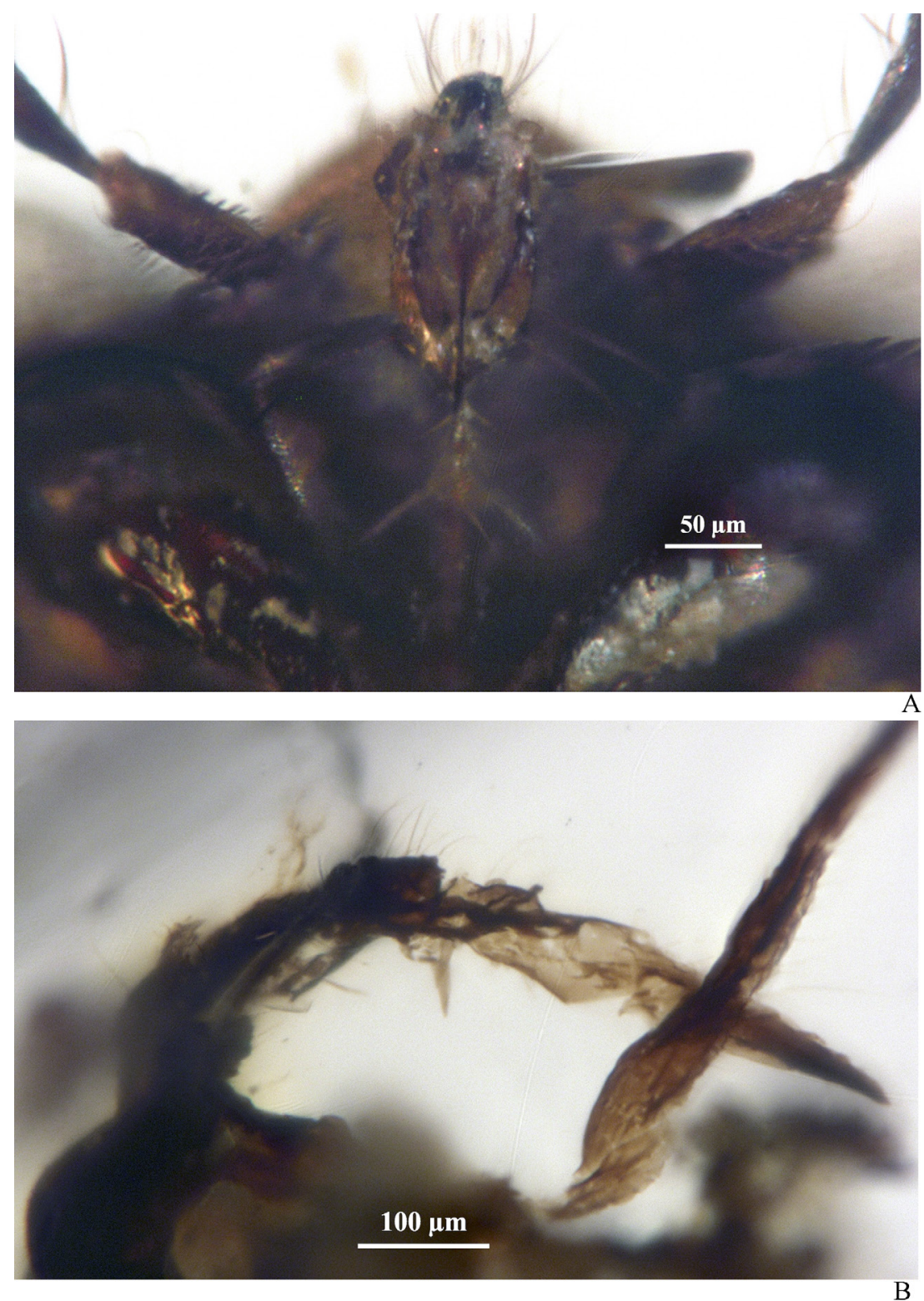

Figure 3 Ventral (A) and lateral (B) view of the mouthparts. The four segments of the labium can be seen from the lateral view (B). 
losomatinae, for the exceedingly large eyes, overlapping the anterolateral margin of pronotum, and the four-segment labium. In this subfamily the third and fourth labial segments often appear connate, so that miscounting is possible, particularly in amber fossils (Hill, 2013).

Forewing venation has been used as a criterion to diagnose several fossil taxa in this subfamily (for example, Hartung et al., 2017; Chen et al., 2019). The specimens studied herein are not macropterous with membranous wings, instead, forewings are elytrous. The characters that distinguish this taxon among others are not the ones used in the systematics of current taxa (for example, genital morphology). Instead, the important diagnostic features are visible characters of the head, legs, and elytrous wings.

Despite the similarity between Hypsotsïilia gen. nov. and Glyptocombus Heidemann 1906, redescribed by Weirauch and Hoey-Chamberlain (2018), the former can be distinguished from the latter by the absence of dense setae in all the surface of the tibiae. Also, Glyptocombus species have elytrous wings, but with different patterns: in $G$. mexicanus Weirauch, in Weirauch, Hoey-Chamberlain and Knyshov 2018 and G. saltator Heidemann, 1906 the elytra are areolate, with very reduced wing cells, or with prominent veins and very narrow and elongate wing cells. In Hypsotsijilia bretoni n. gen., n. sp. wing cells are wider and oval, and the clypeus has at least ten setae. As in Glyptocombus, H. bretoni n. gen, n. sp. presents a pair of thick setae on the buccula, on the first and second labial segment. Nevertheless, the fourth segment has setae at the apex. In addition, the elytral base is narrower than the base of pronotum. Hypsotsijilia n. gen. resembles another New World genus, Ommatides Uhler 1894, recently reviewed (Hoey-Chamberlain and Weirauch, 2019). Unlike Ommatides, Hypsotsïilia n. gen. has prominent wing veins and wider wing cells, oval, not polygonal. It also has a narrow elytral base compared to the pronotum base and the elytral margins; the pronotum is more rectangular than trapezoidal. Hypsotsijilia n. gen. has seven, not five thick setae on the distal half of metatibiae. On the other hand, unlike Hypsohapsis Hoey-Cham- berlain and Weirauch 2016 (a neotropical genus described from Brazil), Hypsotsijilia n. gen. does not have three pairs of ventrolateral macrosetae on the mouthparts, nor areolate forewings. Finally, the clypeus does not have three macrosetae, nor an apical depression, like Hypselosomops Hoey-Chamberlain and Weirauch 2016, a monotypic neotropical genus.

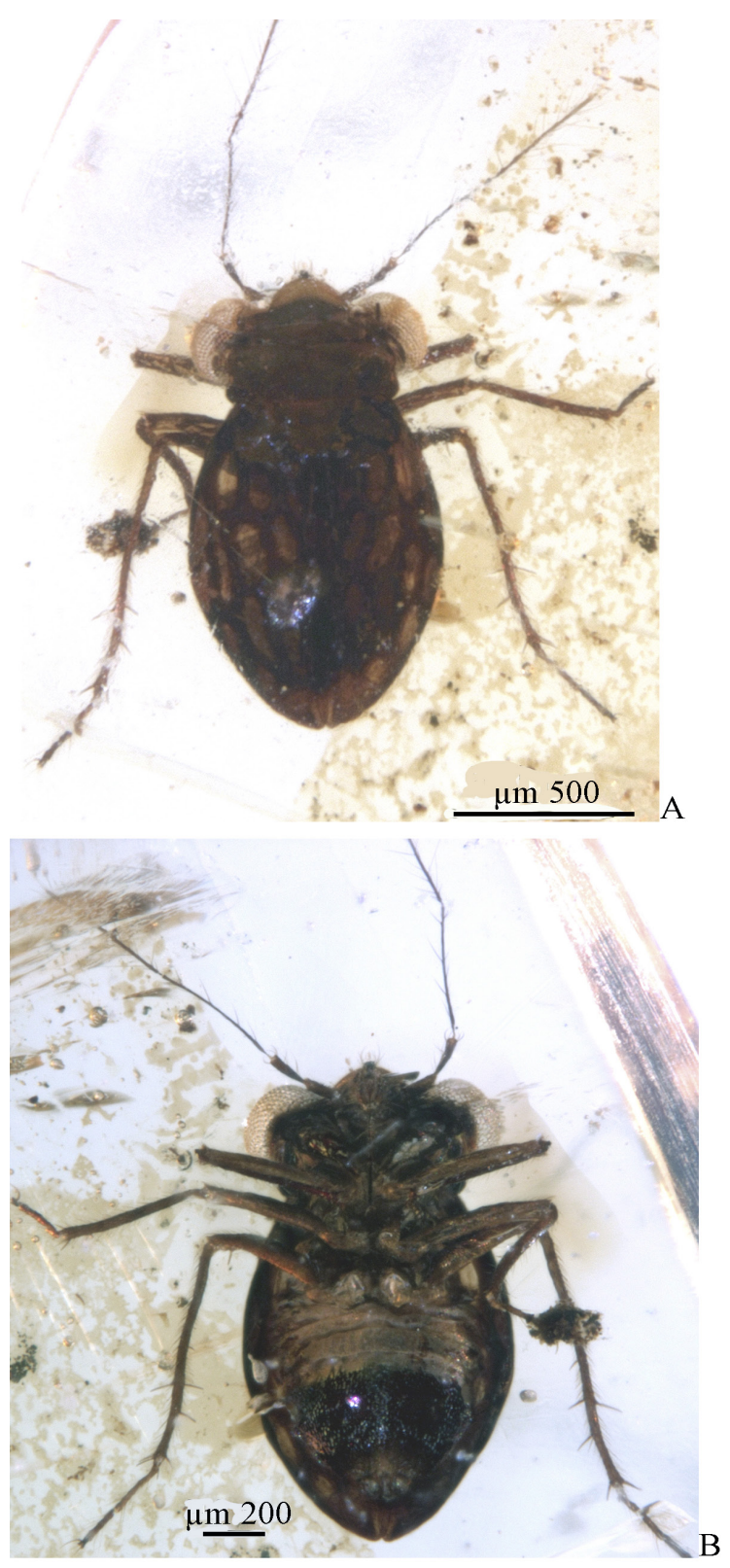

Figure 4 Dorsal (A) and ventral (B) habitus of the holotype. Vein and cell patterns of the elytriform forewing can be appreciated from the dorsal view (A). Antennae and leg characters, such as the type and number of setae are visible, also the general view of the abdomen. 


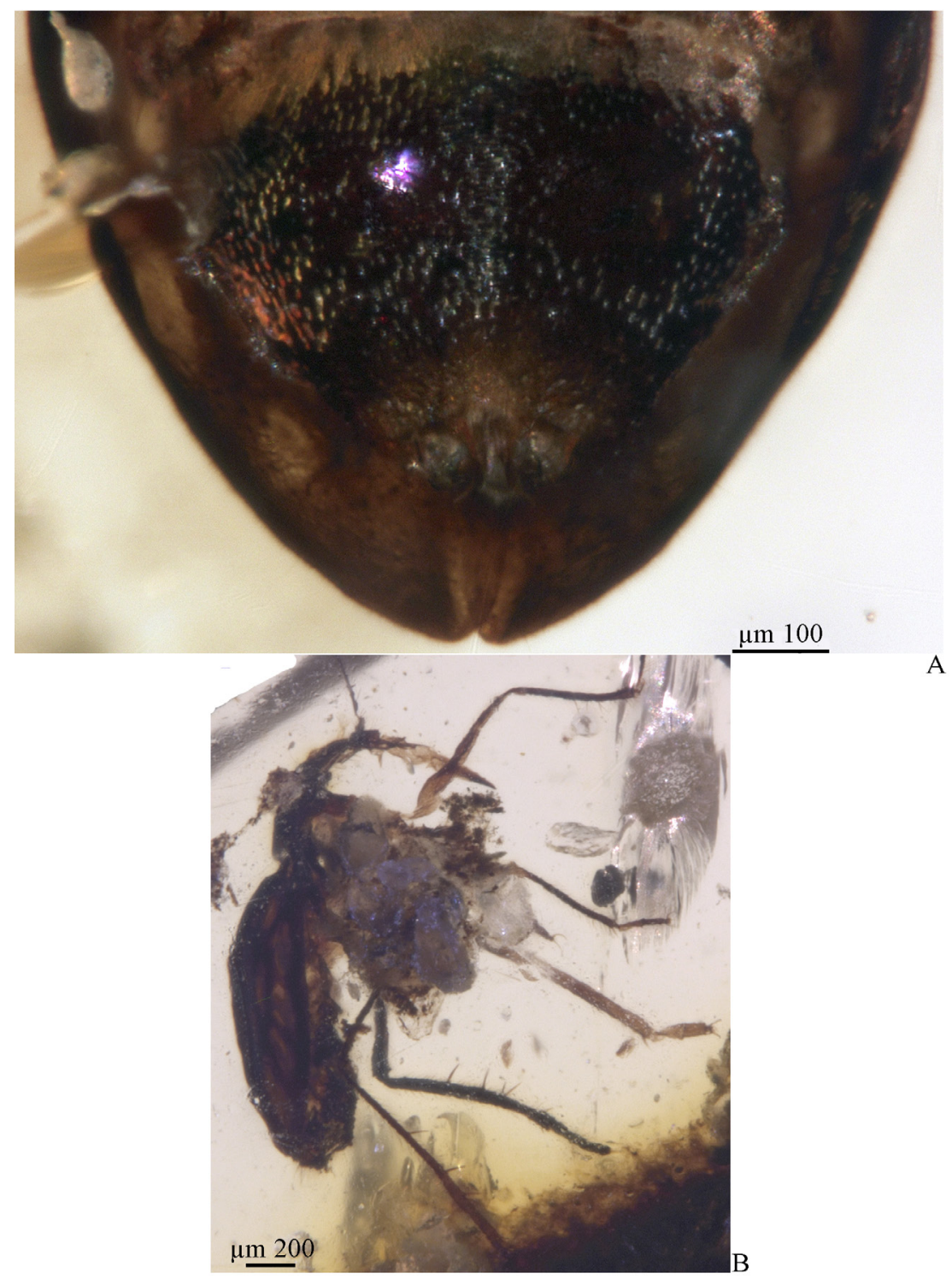

Figure 5 Ventral view of the abdominal apex, the tips of the gonapophysis are visible (A). Lateral habitus of the specimen, setae on the mouthparts and legs are visible, as well as tarsi (B).

\section{Paleoenvironment}

The Hypselosomatinae are found in cryptic microhabitats, being specialized to live in those environments and that may affect their dispersion ability. Most species have been found in litter and low forest regions. Hypselosoma species from Japan and Australia have been found in marine shore environments, such as wet soils near marshes and submerged junks during high tide (Esaki and Miyamoto, 1959; Hill, 1987). Perrichot et al., (2007) documented that the Schizopteridae of Singapore are found below dead wood in mangroves during high tide and emerge to feed on small invertebrates (Collembola and Copepoda) during low tide. Buzinia and Tanaia, described by Perrichot et al., (2007) for Early Cretaceous amber, lived in litter near estuaries and mangroves, feeding on decaying organic matter and microarthropods, which fit the paleoenvironmental model suggested by Serrano-Sánchez et al., (2015) for the Campo La Granja amber. Specimens herein reported belong to an 


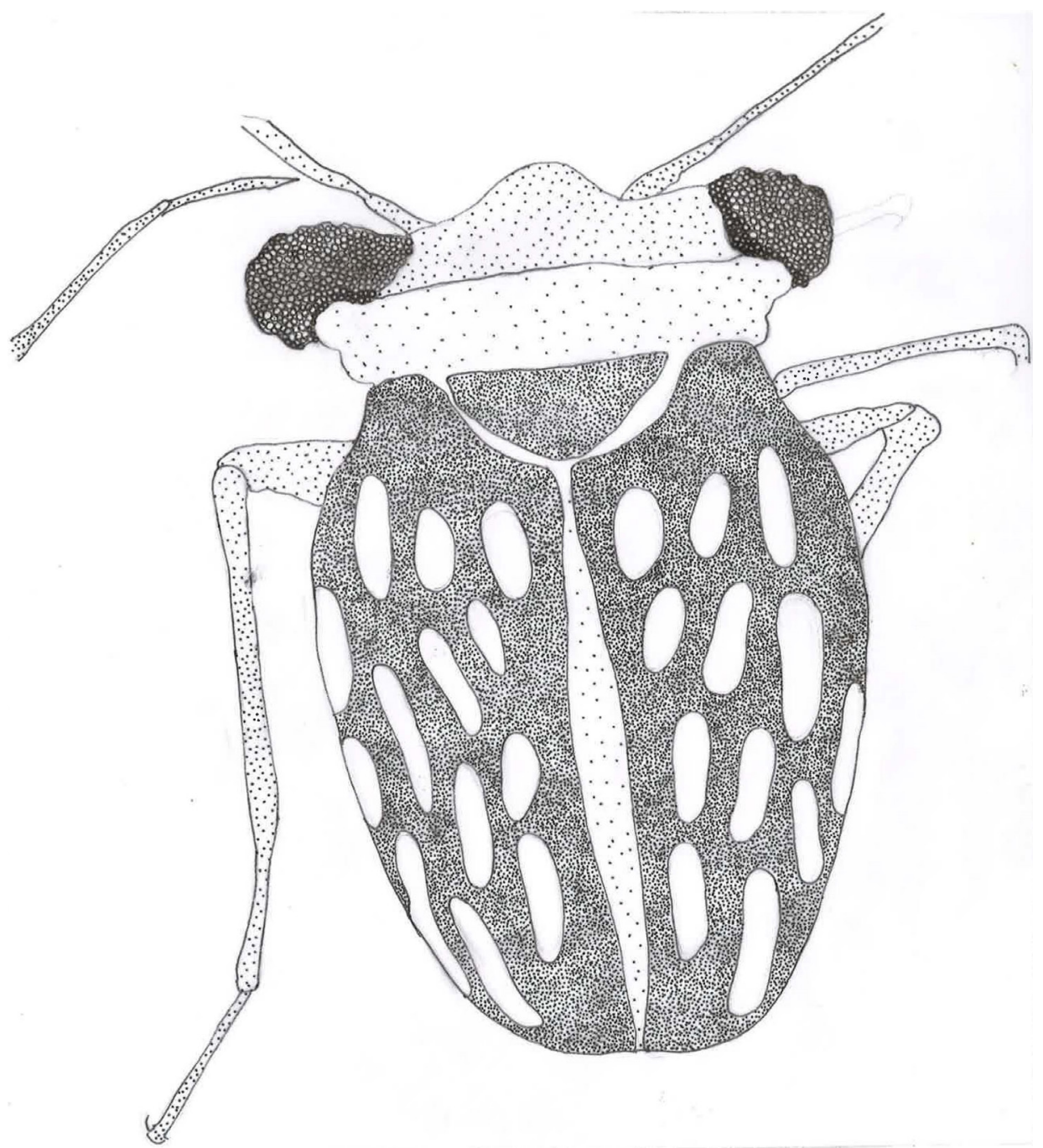

Figure 6 Elytriform forewing of Hypsotsijilia bretoni Cifuentes-Ruiz and Brailovsky gen. et sp. nov. wide cells and veins can be appreciated.

extinct genus, and therefore, phylogenetic relationships with other living taxa are rather obscure, as observed for other arthropods preserved in Mexican amber (Engel, 2004). The knowledge of the taxonomy and distribution of the herein discussed group is reflected by the fact that two of the four known neotropical species were described during the last five years (Hoey-Chamberlain and Weirauch, 2016).

Only two Ceratocombidae species have been described for the amber of Chiapas (Azar et al., 2010). Schizopteridae species are known for the Miocene Dominican amber (Poinar and Brown, 2014). The herein described species increase the past and present diversity of the neotropical Hypselosomatinae, with a current total of five genera and 18 species for the Americas (Almeida et al., 2019; Hoey-Chamberlain and Weirauch, 2019).

\section{Acknowledgements}

Our sincere gratitude to Dr. Flavio Albuquerque (Universidade Federal do Pará (UFPA)-Museu Paraense Emílio Goeldi (MPEG) for constructive and important suggestions to improve the original manuscript. 


\section{References}

Almeida, F.R.A., Carvalho-Filho, F.S., Fernandes, J.A.M., 2019, A new species of Hypsohapsis (Heteroptera: Schizopteridae: Hypselosomatinae) from the Brazilian Amazon: Zootaxa, 4551, 463-470. https:// doi.org/10.11646/zootaxa.4551.4.6

Azar, D., Nel, A., 2010, The earliest fossil schizopterid bug (Insecta: Heteroptera) in the Lower Cretaceous amber of Lebanon: Annales de la Société entomologique de France (N.S.), 46, 193-197. https://doi.org/ 10.1080/00379271.2010.10697657

Azar, D., Nel, A., Coty, D., Garrouste, R., 2010, The second fossil ceratocombid bug from the Miocene amber of Chiapas (Mexico) (Hemiptera: Ceratocombidae): Annales de la Société entomologique de France (N.S.), 46 (12), 100-102. https://doi.org/10.1080/003 79271.2010 .10697642

Broly, P., Serrano-Sanchez, M. de L., Vega, FJ., 2018, Diversity of the crinocheta (Crustacea, Isopoda, Oniscidea) from early Miocene Chiapas amber, Mexico: Revista Mexicana de Ciencias Geológicas, 35(3), 203-214. https://doi.org/10.22201/ cgeo.20072902e.2018.3.639

Calvillo-Canadell, L., Cevallos-Ferriz, S., RicoArce, L., 2010, Miocene Hymenaea flowers preserved in amber from Simojovelde Allende, Chiapas, Mexico: Review of Palaeobotany and Palynolgy, 160 (3-4), 126-134. https:// doi.org/10.1016/j.revpalbo.2010.02.007

Chen, J., Wang, B., Zheng, Y., Zhang, H., 2019, A well-preserved minute litter bug in midCretaceous Kachin amber from northern Myanmar (Heteroptera, Dipsocoromorpha): Cretaceous Research, 96, 6-13. https://doi. org/10.1016/j.cretres.2018.12.003

Cobben, R.H., 1971, A fossil shore bug from the tertiary amber of Chiapas, Mexico (heteroptea: saldidae). Publications in Entomology, vol. 63: USA, University of California, 49-56.
Dohrn, F.A., 1859, Homoptera. Catalogus Hemipterorum. Herausgegeben von dem entomologischen Vereine zu Stettin 1859, 56-93.

Du, B.J., Chen, R., Li, X.Z., Tao, W.T., Bu, W.J., Xiao, J.H., Huang, D.W., 2019, The first amber caridean shrimp from Mexico reveals the ancient adaptation of the Palaemon to the mangrove estuary environment: Scientific Reports, 9(1), 14782. https://doi. org/10.1038/s41598-019-51218-5

Emsley, M.G., 1969, The Schizopteridae (Hemiptera: Heteroptera) with the description of New species from Trinidad: Memoirs of the American Entomological Society, 25, 1-154.

Engel, M.S., 2004, Arthropods in Mexican amber, in Llorente-Bousquets, J.E., Morrone, J.J., Yañez-Ordoñez, O., Vargas-Fernández, I. (eds.), Biodiversidad, Taxonomía y Biogeografía de Artrópodos de México: hacia una síntesis de su conocimiento: México, D.F., Las Prensas de Ciencias, 175-186.

Esaki, T., Miyamoto, S., 1959, A new or little known Hypselosoma from Amani-Oshima and Japan, with proposal of a new tribe for the genus (Hemiptera). Sieboldia: Acta Biologica, 2, 109-120.

Frost, S.H., Langenheim, R.L., 1974, Cenozoic Reef Biofacies, Tertiary Larger Foraminifera and Scleractinian Corals from Chiapas, Mexico. De Kalb (IL): Northern Illinois University Press, 388 p.

García-Villafuerte, M.A., 2009, La araneofauna (Araneae) reciente y fósil de Chiapas, México: Revista Mexicana de Biodiversidad, 80, 633-646.

Graham, A., 1993, Contribution toward a Tertiary palynostratigraphy for Jamaica: the status of Tertiary paleobotanical studies in northern Latin America and preliminary analysis of the guys hill member (Chapelton Formation, middle Eocene) of Jamaica, in Wright, R.M., Robinson, E. (eds.), Biostratigraphy of Jamaica. vol. 182: Geological Society of America, Memoir, 443-461. 
Grimaldi, D., Engel, M.S., 2005, Evolution of the Insects: Cambridge University Press, 770 p.

Hartung, V., Garrouste, R., Nel, A., 2017, The first fossil Dipsocoridae found in the early Eocene amber of France (Hemiptera: Heteroptera): Comptes Rendus Palevol, 16(7), 715-720. https://doi.org/10.1016/j.crpv.2017.05.008

Heard, R.W., Serrano-Sánchez, M.L., Vega, FJ., 2018, Early Miocene Tanaidacea (Crustacea: malacostraca) preserved in amber from Chiapas, Mexico, with the preliminary descriptions of new taxa: Neues Jahrbuch für Geologie und Palaontologie, Abhandlungen, 288(1), 107-120. https://doi.org/10.1127/ njgpa/2018/0726

Hegna, T.A., Lazo-Wasem, E.A., SerranoSánchez, M. de L., Barragán, R., Vega, FJ., 2020, A new fossil talitrid amphipod from the lower early Miocene Chiapas amber documented with microCT scanning: Journal of South American Earth Sciences, 98, 102462. https://doi.org/10.1016/j. jsames.2019.102462

Heidemann, O., 1906, A new genus and species of the hemipterous family Ceratocombidae from the United States: Proceedings of the Entomological Society of Washington, 7, 192-194.

Henry, T. J., 2009, Biodiversity of Heteroptera, in Foottit, R. G., Adler, P.H., (eds.), Insect Biodiversity. Science and Society: USA, Wiley-Blackwell, 223-255. https://doi. org/10.1002/9781444308211

Hill, L., 1984, New Genera of Hypselosomatinae (Heteroptera: Schizopteridae) from Australia: Australian Journal of Zoology, 103, 10311055. https://doi.org/10.1071/ajzs 103

Hill, L., 1987, Four new Australian species of Hypselosoma Reuter (Heteroptera: Schizopteridae): Australian Journal of Entomology, 26 (3), 265-278. https://doi. org/10.1111/j.1440-6055.1987.tb00300.x

Hill, L., 1991, Hypselosoma acanteen n. sp. (Heteroptera: Schizopteridae), first record of the family in New Zealand: New Zealand
Journal of Zoology, 18 (1), 76-81. https:// doi.org/10.1080/03014223.1991.10757950

Hill, L., 2013, A revision of Hypselosoma Reuter (Insecta: Heteroptera: Schizopteridae) from New Caledonia: Memoirs of the Queensland Museum, 56, 407-455.

Hoey-Chamberlain, R., Weirauch, C., 2016, Two new genera of big-eyed minute litter bugs (Hemiptera, Schizopteridae, Hypselosomatinae) from Brazil and the Caribbean: ZooKeys, 640, 79-102. https:// doi.org/10.3897/zookeys.640.9690

Hoey-Chamberlain, R., Weirauch, C., 2019, Taxonomic revision of the New World big eyed minute litter bug genus Ommatides Uhler (Hemiptera: Schizopteridae): Zootaxa, 4585(1), 73-99. https://doi.org/10.11646/ zootaxa.4585.1.5

Huys, R., Suárez-Morales, E., Serrano-Sanchez, M. de L., Centeno-García, E., Vega, F.J., 2016, Early Miocene amber inclusions from Mexico reveal antiquity of mangroveassociated copepods: Scientific Reports, 6(1), 34872. https://doi.org/10.1038/srep34872

Knyshov, A., Weirauch, C., Hoey-Chamberlain, R., 2020, Phylogenetic relationships and revised classification of the true bug infraorder Dipsocoromorpha (Insecta: Hemiptera: Heteroptera): Cladistics, 1-28. https://doi.org/10.1111/cla.12435

Langenheim, J.H., 1995, Biology of amberproducing trees: focus on case studies of Hymenaea and Agathis, in Anderson, K.B., Crelling, J.C. (eds.), Amber, Resinite and Fossil Resins:Washington, DC, American Chemical Society, 1-31.

Langenheim, J.H., Hackner, B.L., Bartlett, A., 1967, Mangrove pollen at the depositional site of oligo-miocene amber from Chiapas, Mexico: Botanical Museum Leaflet, Harvard University, 21(10), 289-324.

Latreille, P.A., 1810, Considérations générales sur l'ordre natural des animaux composant les classes des Crustacés, des Arachnides et des Insectes; avec un tableau méthodique des 
leurs genres disposées en familles: Paris, Chez F. Schoell, $444 \mathrm{p}$.

Linnaeus, C., 1758, Systema naturae per regna tria naturae, secundum classes, ordines, genera, species, cum characteribus, differentiis, synonymis, locis.Editio decima, reformata [10th revised edition], vol. 1: Vindobonae [Vienna], Typis Ioannis Thomae, 824 p.

Matzke-Karasz, R., Serrano-Sánchez, M. de L., Perez, L., Keyser, D., Pipik, R., Vega, FJ., 2019, Abundant assemblage of Ostracoda (Crustacea) in Mexican Miocene amber sheds light on the evolution of the brackishwater tribe Thalassocypridini: Historical Biology, 31(2), 65-100. https://doi.org/10.1 080/08912963.2017.1340471

Miyamoto, S., 1961, Comparative morphology of the alimentary organs of Heteroptera with phylogenetic considerations: Sieboldia, 2(4), 197-259.

Perrichot, V., Nel, A., Néraudeau, D., 2007, Schizopterid bugs (Insecta: Heteroptera) in Mid-Cretaceous ambers from France and Myanmar (Burma): Palaeontology, 50(6), 1367-1374. https://doi. org/10.1111/j.1475-4983.2007.00721.x

Poinar Jr., G.O., 1992, Life in amber: Palo Alto (CA), Stanford University Press, $350 \mathrm{p}$.

Poinar Jr., G.O., Brown, A.E., 2002, Hymenaea mexicana sp. nov. (Leguminosae: caesalpiniodeae) from Mexican amber indicates Old World connections: Botanical Journal of the Linnean Society, 139(2), 125-132. https://doi. org/10.1046/j.1095-8339.2002.00053.x

Poinar, G. Jr., Brown, A., 2014, New genera and species of Jumping Ground Bugs (Hemiptera: Schizopteridae) in Dominican and Burmese amber, with a description of a meloi (Coleoptera: Meloidae) triungulin on a Burmese specimen: Annales de la Société entomologique de France (N.S.), 50 (3-4), 372-381. https://doi.org/10.1080/0037927 1.2014 .982025

Reuter, O.M., 1891, Monographia Ceratocombidarum orbis terrestres: Acta
Societatis Scientiarum Fennicae, 19, 1-28. Serrano-Sánchez, M. de L., Hegna, T. A., Schaaf, P., Pérez, L., Centeno-García, E., Vega, F.J., 2015, The aquatic and semiaquatic biota in Miocene amber from the Campo La Granja mine (Chiapas, Mexico): Paleoenvironmental implications: Journal of South American Earth Sciences, 62, 243-256. https://doi.org/10.1016/j. jsames.2015.06.007

Serrano-Sánchez, M.L., Nagler, C., Haug, C., Haug, J.T., Centeno-García, E., Vega, F.J., 2016a, The first fossil record of larval stages of parasitic isopods: cryptoniscus larvae preserved in Miocene amber: Neues Jahrbuch für Geologie und Palaontologie, Abhandlungen, 279(1), 97-106. https://doi. org/10.1127/njgpa/2016/0543

Serrano-Sánchez, M.L., Guerao, G., CentenoGarcia, E., Vega, F.J., 2016b, Crabs (Brachyura: Grapsoidea: Sesarmidae) as inclusions in Lower Miocene amber from Chiapas, Mexico: Boletín de la Sociedad Geológica Mexicana, 68(1), 37-43. https:// doi.org/10.18268/bsgm2016v68nla6

Solórzano-Kraemer, M.M., 2010, Mexican amber, in Penney, D. (ed.), Biodiversity of fossils in amber from the major world deposits: Manchester, Siri Scientific Press, 42-56.

Štys, P., 1995, Dipsocoromorpha, in Schuh, R.T., Slater, J.A. (eds.), True bugs of the world (Hemiptera: Heteroptera): classification and natural history: Cornell University Press, 74-83.

Uhler, P.R., 1894, A list of the HemipteraHeteroptera of the families Anthocoridae and Ceratocombidae collected by $\mathrm{Mr}$. $\mathrm{H}$. H. Smith in the island of St. Vincent, with descriptions of new genera and species: Proceedings of the Zoological Society of London, 156-160.

Weirauch, C., Fernandes, J.A.M., 2015, The minute litter bugs (Dipsocoromorpha), in Panizzi, A. R., Grazia, J. (eds.), True bugs (Heteroptera) of the Neotropics: 
Dordrecht, Springer, 99-109. https://doi. org/10.1007/978-94-017-9861-7_5

Weirauch, C., Frankenberg, S., 2015, From "insect soup" to biodiversity discovery; taxonomic revisión of Peloridinannus Wygodzinksy, 1951 (Hemiptera: Schizopteridae), with description of six new species: Arthropod Systematics and Phylogeny, 73, 457-475.
Weirauch, G., Hoey-Chamberlain, R., Knyshov, A., 2018, Synopsis of Schizopteridae (Hemiptera, Heteroptera, Dipsocoromorpha) from the United States, with description of seven new species from the US and Mexico: ZooKeys, 796, 49-82. https://doi.org/10.3897/ zookeys.796.24176 